\title{
ABC Model of Research Productivity and Higher Educational Institutional Ranking
}

\author{
P. Sreeramana Aithal ${ }^{*}$, Suresh Kumar P. M.
}

Srinivas Institute of Management Studies, Pandeshwar, Mangalore - 575 001, INDIA

\begin{abstract}
Institutional Ranking has become a common practice in higher educational institutions, and business schools are the most benefitted by such ranking announced worldwide based on various ranking criteria. The ranking is usually based on pedagogy, placement, research output, faculty-student ratio, international linkage, management of technology etc. In this paper, based on six postulates, we have argued and analysed why the performance of higher educational institutions should be based on sole criteria of Institutional Research Performance (IRP). We have developed a model of measuring research productivity for higher educational institutions based on calculating institutional research index and weighted research index. The institutional research productivity is calculated using a metric which consists of three institutional variables and one parameter. The three variables identified are the following: Number of Articles published in peer reviewed journals (A), Number of Books published (B), and Number of Case studies and/or Book Chapters (C) published during a given time of observation. The parameter used is a number of full-time Faculty members (F) which remains constant during a given period of observation. A framework for institutional ranking based on institutional research productivity by considering calculated Institutional Research Index is also developed which can be used to give grades to higher educational institutions. Further, the model is tested by making use of case example of two best Business Schools from the USA and two best Business Schools from India. The value of research index and weighted research index are calculated for these institutions and observed variation of research productivity during last four years is also studied and discussed.
\end{abstract}

Index Terms: Business school ranking, Faculty productivity, Institutional research productivity, Institutional research productivity index.

(C) 2016 Published by MECS Publisher. Selection and/or peer review under responsibility of the Research Association of Modern Education and Computer Science.

\section{Introduction}

A Business School is a university-level institution that confers degrees in business administration or

* Corresponding author:

E-mail address: psaithal@ srinivasgroup.com 
management. Such a school is also called as a school of management, school of business, school of business administration, or, colloquially, b-school or biz school. A business school teaches various subjects such as accounting, management principles, business environment, administration, strategy, economics, entrepreneurship, finance, human resource management, information systems, logistics, marketing, organizational psychology, organizational behavior, public relations, research methods, decision science, ebusiness, international business, entrepreneurship, real estate etc. Business schools, in general, use different pedagogy to educate their students. Most of the business schools use the concept of the lecture-based method to give students a basic business education. Lectures are generally given from the professor's point of view, and rarely require interaction from the students unless note taking is required. Some business schools center their teaching around the use of case studies. Business cases are historical descriptions of actual business situations. Typically, information is presented about a business firm's products, markets, competition, financial structure, sales volumes, management, employees and other factors affecting the firm's success. Some business schools use a skills-based approach emphasizing quantitative methods, in particular, operations research, management information systems, statistics, organizational behavior, modeling and simulation, and decision science. Some business schools, in addition to concept based teaching, use business games in different disciplines such as business, economics, management, etc. Some business schools are blending many of these approaches throughout their degree programs, and even blending the method of delivery for each of these approaches. Using above pedagogy, business schools strive to meet two goals: knowledge exploration through research and knowledge exploitation through instruction. The instruction imparted in business schools are mainly derived from research and hence the knowledge exploration through research finds central activity in business schools.

Recently introduced business school ranking system based on various criteria and parameters is helpful to study and compare the quality of knowledge and skills imparted in these business schools. Business school ranking also helps student aspirants to choose the school and the programme to pursue their education with required competitive edge to be suitable to get absorbed in industries. Ranking is based on pedagogy [1], placement [2], research output [3], faculty-student ratio [4], international linkage [5], management of technology [6] etc. The validity and relevance of rankings of business schools and programmes are directly related to the choice of criteria against which the ranking takes place [7]. Recently an Indian news firm, 'Business Today' announced Indian best schools ranking based on five criterion namely: learning experience, living experience, selection process and establishment, future orientation, and placement performance [8]. This is not a scientific way of measuring the higher educational institutions performance due to the fact that these parameters are not measurable and quantifiable systematically. These parameters used in various higher institutional (especially business schools) ranking depends on environmental factors and hence different at different locations and countries.

In this paper, we argue that the institutional quality in the higher education system should not be measured based on the quality input of admitted students, the infrastructure provided, the academic result achieved, the international exposure, the amount of fee the institution is charging on students and the placement performance. Institutional productivity and performance should not be measured based on number of industry linkage, number of Management Development Programmes (MDP) \& Faculty Development Programmes (FDP) it conducted, the amount of money through consultation and the number and amount of funding it received through projects, but the performance of higher education institution should be based on the 'New Knowledge' it has created. Here, we are proposing an institutional ranking standard based on institutional research productivity which is in turn based on faculty research output. Out of various criteria of ranking system mentioned above, faculty research output (or faculty productivity) is the deserved criteria for business school ranking. All other criteria/parameters depend on faculty ability to decide on the model of training. A business school can be effective if the faculty members are very active in research and finding new optimum solutions to the industry problems. The quality and the reputation of a business school depends on the effort of faculty members in involving students in research projects and case developments. This will enhance the student's ability to do innovation in industries. Such graduates will carry values and ideas to the industry to identify new business opportunities. To support our model, we have studied the research publication performance of some of 
the top ranking business schools in India and abroad and developed a metric of assessment for research productivity output for last 3 years.

\section{Institutional Research Productivity Model (ABC Model)}

Recently the Ministry of Human Resource Development, Govt. of India has developed a National Institutional Ranking Framework [9] which uses various criteria and parameters that have global appeal e.g. research output, research impact, learning environment, etc. The framework has also considered parameters like infrastructure, facilities for differently-abled persons, the percentage of students from other states and other countries, the percentage of women students and faculty, and percentage of economically and disadvantaged students. The framework has also given weightage to the sports and extra-curricular facilities available on the campuses of universities, which supports the overall development of a student in a Business school or a University. But we argue that all other facilities like infrastructure, student development facilities, library and laboratory facilities, faculty-student ratio etc. are already standardized by national accreditation bodies and the graduation outcome cannot be quality measurement criteria for autonomous institutions. The Outreach and Inclusivity parameters depend on the objective of the organization and the perception parameter depend on the innovation ability and research productivity of the organization and hence the only criterion which should be used to decide the quality and hence the ranking of the organization should be institutional research productivity which is a measure of institutional effectiveness.

In our model of studying institutional effectiveness, which in turn depend on the institutional research productivity of both faculty and students of the higher educational institution (figure 1), we have developed a scheme of measuring institutional performance based on following postulates.

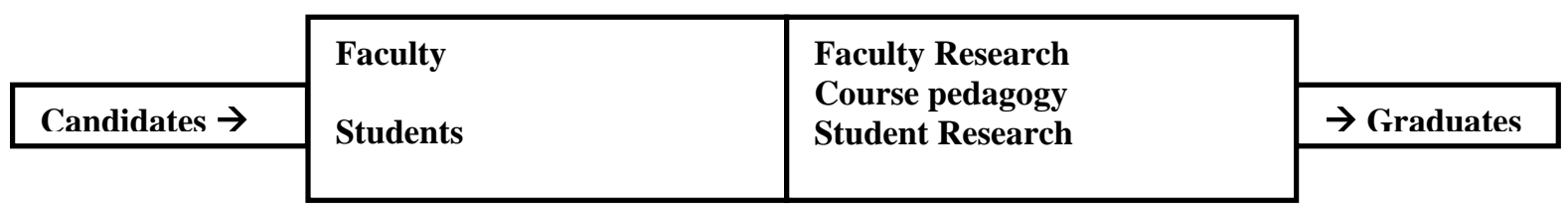

Fig.1. System model of a Business School

Postulate 1: The Quality of higher education depends on the ability of the institution in new knowledge creation.

Postulate 2: The ability of new knowledge creation of the institution depends on the institutional research and publications by both faculty members and students.

Postulate 3: The institutional publication is measured by calculating its annual average publications.

Postulate 4: The institutional publication ability is measured by its annual publications in terms of the number of Articles published in Journals (A), the number of Books published in the subjects/Edited volumes (B), and the number of Business cases and Book chapters (C) published.

Postulate 5: The Research productivity (P) of the institution can be measured by knowing research index $(\alpha)$ and weighted research index $(\beta)$, which shall be calculated using average publications in Journals, average publications of books and an average number of publications of Business cases.

The research index per year $(\alpha)$ is calculated using the formula $\alpha=(2 \mathrm{~A}+5 \mathrm{~B}+\mathrm{C}) / \mathrm{F}$, and the weighted research index $(\beta)$, per year, is calculated using the formula $\beta=(2 \mathrm{~A}+5 \mathrm{~B}+\mathrm{C}) / 8 \mathrm{~F}$, where $\mathrm{A}=$ No. of publications in Journals in that year, $\mathrm{B}=$ No. books published in that year, $\mathrm{C}=$ No. of Publications of Business Cases published in that year, and $\mathrm{F}=$ No. of full-time Faculty members in that institution during that year. In the above formula, the weightage for a research article A is two and that of book B is five and the case study is one, based on a quantified assumption of the relative significance \& efforts involved in generating it arrived at through a summated scaling technique.

Postulate 6: The annual research productivity (research index $\alpha$ ) of the organization decides institutional 
ranking. If $\alpha<3$, the Business school is poor in Research Productivity, if $\alpha=3$, the Business School is sustainable if $\alpha>3$, the institution is good and $\alpha>5$ for top business schools and only such institutions should be considered for global Ranking.

The last postulate will give an idea for Institutional administrators of what productivity level the organization should maintain to improve its brand. The faculty members who fail to contribute to the research in addition to their teaching workload, to improve annual research productivity to the desired level should be relieved from the job. Since the annual research productivity decides the quality of the higher educational institution, there is a continuous pressure on all the faculty members to involve in research activities and best performers in the team should get incentives from the organization.

\section{Calculation of Institutional Research Index}

The institutional research performance can be calculated by considering the different ways of new knowledge creation. All institutional effort to improve teaching-learning process should be focused towards developing students' research and innovating ability which in turn depends on faculty guidance on creating a new idea, concept, methods and the analysing ability of problems for effective decision making. Students through the theoretical study of concepts, experimental study through projects/fieldwork should be capable of publishing research papers, book chapters, and/or case studies. Through forming research teams which include both faculty members and students, the higher educational institution has the responsibility towards creating new knowledge, developing new skills and imparting new experience through research and innovation. All other aspects and parameters for enhanced performance in higher educational institutions like obtaining project funding, providing industry consultation, applying patents etc. are subsidiary requirements because their further effectiveness also depends on the research outcome of the organization in the form of publications. In this model, we have four types of research publications namely Journal publications, Book publication, Book chapter publication and Business Case publication. Any other type of publication like the publication of papers in conferences/proceedings requires to be further improved and converted as journal publication and hence such publications are not counted for calculation of the index. By considering such effective research publications, $\mathrm{ABC}$ model of institutional productivity can be calculated. In $\mathrm{ABC}$ model, $\mathrm{A}$ stands for the number of research articles published in reviewed journals, B stands for the number of Books published with unique ISBN number, and $\mathrm{C}$ stands for the number of business cases and/or number of book chapters published by the institution during a given year.

Research index is calculated using following formulae:

Research productivity index of the Higher Education Institution $=(2 \mathrm{~A}+5 \mathrm{~B}+1 \mathrm{C}) / \mathrm{F}$, where $\mathrm{A}$ is number of papers published in reviewed \& indexed Journals with ISSN number during a given year, B is number of books published with ISBN number during a given year, and $\mathrm{C}$ is sum of number of business cases and book chapters published during a given year. $\mathrm{F}$ is number full-time faculty members of the institution during a given year.

Institutional Research productivity index $=[(2 \mathrm{~A}+5 \mathrm{~B}+1 \mathrm{C}) / \mathrm{F}]$

\section{Calculation of Institutional Weighted Research Index}

The weighted average is an average in which each quantity to be averaged is assigned a weightage. These weightages determine the relative importance of each quantity on the average. Weightages are the equivalent of having that many like items with the same value involved in the average. Weighted Research productivity index of the Higher Education Institution are calculated using following formula:

Weighted Research Productivity index $=[(2 \mathrm{~A}+5 \mathrm{~B}+1 \mathrm{C}) / 8] / \mathrm{F}$ 
Where $\mathrm{A}$ is the number of papers published in reviewed \& indexed Journals with ISSN number during a given year, B is the number of books published with ISBN number during a given year, and $\mathrm{C}$ is the sum of the number of business cases and book chapters published during a given year. $F$ is number full-time faculty members during a given year.

By examining the value of calculated weighted Research productivity index, we can classify a given higher education institution as five categories as Best, Better, Good, Satisfactory and Non-performer as shown in Table 1.

Table 1. Institutional Grading based on Research Productivity \& Weighted Research Productivity

\begin{tabular}{|c|c|c|}
\hline Value of research index $(\alpha) \geq$ & Value of weighted research index $(\beta) \geq$ & Grade \\
\hline 24 & 3 & Optimum \\
\hline 16 & 2 & Best \\
\hline 08 & 1 & Better \\
\hline 04 & 0.5 & Satisfactory \\
\hline 03 & 0.375 & Poor \\
\hline 02 & 0.25 & Nonperformer \\
\hline 01 & 0.125 & \\
\hline
\end{tabular}

\section{Case Examples}

\section{(1). Harvard Business School:}

Harvard Business School is a Private graduate business school of Harvard University in Boston, Massachusetts, United States. Established in 1908, the school offers full-time MBA program, doctoral program, many other executive education programs. The school is consistently ranked among the leading business schools in the world as per the U.S. News \& World Report ranking. Harvard Business School as third in the world during 2014 Universal Business School Ranking. The school has admitted 936 MBA students for the year 2016. The school's faculty are divided into ten academic units: Accounting and Management; Business, Government and the International Economy; Entrepreneurial Management; Finance; General Management; Marketing; Negotiation, Organizations \& Markets; Organizational Behavior; Strategy; and Technology and Operations Management. The school has 260 full-time faculty members and eight research centers [10].

The research publications (A), Books written/edited (B), and the book chapters \& Case studies published (C) during last four years for selected business schools as obtained from their institutional website is listed in Table 2. 
Table 2. ABC Values of some Top Business Schools for Last 4 Years

\begin{tabular}{|c|c|c|c|c|c|c|c|}
\hline S.No. & Institution & $\begin{array}{c}\text { No. of Faculty } \\
\text { Members }\end{array}$ & Year & $\begin{array}{c}\text { Articles } \\
\text { Published A }\end{array}$ & $\begin{array}{c}\text { Books } \\
\text { Published B }\end{array}$ & $\begin{array}{c}\text { Book } \\
\text { Chapter C }\end{array}$ & $\begin{array}{c}\text { Case } \\
\text { Studies C }\end{array}$ \\
\hline \multirow{4}{*}{1} & \multirow{4}{*}{$\begin{array}{l}\text { Wharton Business } \\
\text { School, University of } \\
\text { Pennsylvania, } \\
\text { USA }\end{array}$} & \multirow{4}{*}{266} & 2015 & 253 & 15 & 09 & - \\
\hline & & & 2014 & 339 & 13 & 26 & - \\
\hline & & & 2013 & 344 & 17 & 19 & - \\
\hline & & & 2012 & 375 & 17 & 21 & - \\
\hline \multirow{4}{*}{2} & \multirow{4}{*}{$\begin{array}{l}\text { Harvard Business } \\
\text { School, USA }\end{array}$} & 286 & 2015 & 207 & 11 & 39 & 309 \\
\hline & & 234 & 2014 & 193 & 18 & 30 & 324 \\
\hline & & 227 & 2013 & 181 & 17 & 31 & 321 \\
\hline & & 232 & 2012 & 184 & 23 & 56 & 309 \\
\hline \multirow{4}{*}{3} & \multirow{4}{*}{$\begin{array}{l}\text { IIM, } \\
\text { India }\end{array}$} & \multirow{4}{*}{143} & 2015 & 55 & 04 & 19 & 80 \\
\hline & & & 2014 & 98 & 15 & 33 & 92 \\
\hline & & & 2013 & 69 & 18 & 04 & 102 \\
\hline & & & 2012 & 95 & 14 & 18 & 109 \\
\hline \multirow{4}{*}{4} & \multirow{4}{*}{$\begin{array}{l}\text { Indian School of } \\
\text { Business, Hyderabad, } \\
\text { India }\end{array}$} & \multirow{4}{*}{45} & 2015 & 30 & 01 & - & 32 \\
\hline & & & 2014 & 30 & 08 & - & 36 \\
\hline & & & 2013 & 40 & 05 & - & 69 \\
\hline & & & 2012 & 34 & 05 & - & 21 \\
\hline
\end{tabular}

The index worked out for HBS is given below:

Annual Research index for $2015=(2 \mathrm{~A}+5 \mathrm{~B}+\mathrm{C}) / \mathrm{F}=(414+55+348) / 286=2.86$

Annual Weighted Research index for $2015=(2 \mathrm{~A}+5 \mathrm{~B}+\mathrm{C}) / 8 \mathrm{~F}=2.86 / 8=0.357$

\section{(2) Wharton Business School:}

The Wharton School of the University of Pennsylvania is the business school of the University of Pennsylvania, located in Philadelphia. Established in 1881 through a donation from Joseph Wharton, Wharton is widely regarded as one of the world's top institutions for business education. The undergraduate program at the Wharton School has been ranked number one by U.S. News \& World Report every single year since inception. In 2014-2015, the U.S. News \& World Report ranked Wharton's undergraduate program first, MBA program first, and executive MBA program also first, making Wharton the only school to ever be ranked number one in all three categories simultaneously. Between 2000 and 2009, the Financial Times has ranked the Wharton School first in the world in every single year. Again in 2011, Wharton was conferred the best overall performance in the business school rankings. The Wharton School has also been ranked number one by Bloomberg Business week four times in a row. U.S. News \& World Report's "best finance programs" list Wharton as best in each consecutive year from its commencement. The Wharton School at University of Pennsylvania offers these departments and concentrations: accounting, actuarial science, e-commerce, economics, entrepreneurship, finance, general management, health care administration, human resources management, insurance, international business, marketing, production/operations management, public policy, real estate, and quantitative analysis/statistics and operations research. Wharton's 20 research centers and initiatives reflect the diversity and depth of research interests and activity at the School. Based on publications in 24 of the world's leading peer-reviewed journals, Wharton holds the top position in research productivity, and held the top rank in research productivity each year since 1986 [11]. Wharton's 225-plus professors generate the knowledge and innovations that transform global business practice and public policy. Drawn from 10 distinct departments, they work with leading companies and policy-makers around the world, and they bring that real-world, real-time knowledge into Wharton's classrooms and 20 research centres and initiatives. The research publications (A), Books written/edited (B), and the book chapters \& Case studies 
published $(\mathrm{C})$ during last four years as obtained from their institutional website is listed in Table 2 .

Accordingly, the following indices are worked out:

Annual Research index for $2015=(2 \mathrm{~A}+5 \mathrm{~B}+\mathrm{C}) / \mathrm{F}=(506+75+0) / 266=2.22$

Annual Weighted Research index for $2015=(2 \mathrm{~A}+5 \mathrm{~B}+\mathrm{C}) / 8 \mathrm{~F}=(506+75+0) / 8 \times 266=0.2773$.

\section{(3) Indian Institute of Management, Ahmedabad:}

Among Indian business schools, IIM Ahmedabad occupy a prominent position to be ranked number one in India. With 143 faculty members during year 2015, drawn from different disciplinary backgrounds, teaching, and research interests, IIMA conducts it academic programmes through a number of clearly defined areas. The faculty has the flexibility to initiate inter-disciplinary groups to address issues and management challenges that require a multi-disciplinary approach. The faculty members have the flexibility to address management challenges through multi-disciplinary approach by initiating inter-disciplinary research through collaborations from members in different areas. One faculty member is designated as chairperson for each Area and he coordinates the various activities related to developing and running academic programs [12]. The research publications (A), Books written/edited (B), and the book chapters \& Case studies published (C) during last four years as obtained from their institutional website is listed in Table 2.

The index worked out for IIM, Ahmedabad is as follows:

Annual Research index for $2015=(2 \mathrm{~A}+5 \mathrm{~B}+\mathrm{C}) / \mathrm{F}=(110+20+99) / 143=229 / 143=1.60$

Annual Weighted Research index for $2015=(2 \mathrm{~A}+5 \mathrm{~B}+\mathrm{C}) / 8 \mathrm{~F}=1.60 / 8=0.2$

\section{(4) Indian School of Business, Hyderabad:}

Founded in 2001, Indian School of Business, a private business school in India with campuses at Hyderabad and Mohali, is a nonprofit organization. The school was founded by two senior executives of McKinsey \& Company and is governed by a board comprising both Indian and non-Indian businessmen. ISB has been ranked 33rd in the world in the 2015 Financial Times Global MBA Rankings. ISB is the first business school in the Indian subcontinent to be accredited by the Association to Advance Collegiate Schools of Business. However, ISB is not accredited by the Indian statutory body, the All India Council for Technical Education (AICTE). ISB has chosen not to apply for accreditation by AICTE as it offers neither a diploma nor a degree. In 2008, ISB became the youngest institution to find a place in global MBA rankings when it was ranked 20. ISB has six academic areas which include: Accounting, Marketing, Finance, Strategy, Operations and Technology, and Organizational Behaviour. Through Centers of Excellency, ISB connects industry and academia to advance education, research, and outreach in key areas. The five Centers of excellence are (1) Centre for Analytical Finance, (2) Centre for Entrepreneurship, (3) Centre for Teaching, Learning, and Case Development, (4) Srini Raju Centre For IT and The Networked Economy, (6) Thomas Schmidheiny Centre for Family Enterprise. In ISB, there are four institutes at the ISB that target areas critical to India's growth: (1) Bharti Institute of Public Policy, (2) Max Institute of Healthcare Management, (3) Munjal Institute for Global Manufacturing, and (4) Punj Lloyd Institute of Infrastructure Management [13]. The research publications (A), Books written/edited (B), and the book chapters \& Case studies published (C) during last four years as obtained from their institutional website is listed in Table 2.

The index worked out for ISB, Hyderabad is as follows:

Annual Research index for $2015=(2 \mathrm{~A}+5 \mathrm{~B}+\mathrm{C}) / \mathrm{F}=(62+05+32) / 45=2.16$

Annual Weighted Research index for $2015=(2 \mathrm{~A}+5 \mathrm{~B}+\mathrm{C}) / 8 \mathrm{~F}=2.16 / 8=0.270$

Research Productivity based on Research index of four Top Business Schools for the four consecutive years 
is provided in Table 3 .

The weighted research index for all four top business schools shows that the research productivity and hence competency of these Higher education institutions are decreasing in many cases during the observed period of last four years and is not increasing year after year. Even though the full-time faculty members have many research scholars working under them, the research productivity of the full-time faculty members considered altogether is not encouraging. Assuming that a faculty member with Ph.D. research qualification should be capable of publishing 4 papers (A), 2 books (B) and 6 business cases/book chapters per year in a good/top business school, the average institutional research index will be $\alpha=(8+10+6) / 1=24$ instead of between 2.22 to 3.33 as in case of Wharton Business School, between 2.86 to 3.66 in case of Harvard Business School, between 1.60 to 2.77 in case of IIM, Ahmedabad, and between 2.16 to 3.87 in case of ISB, Hyderabad. Therefore, it could be suggested that the performance of even top higher educational institutions in research front and consequently their productivity are diminishing. For the above case, the optimum weighted research index becomes $\beta=\alpha / 8=24 / 8=3$. But it is as per table 4 , the top business schools $\beta<0.5$, which is not encouraging. These institutions have to target their average research productivity to $\alpha=24$ in order to raise their research competency to the optimum level.

Table 3. Research index of four Top Business Schools

\begin{tabular}{|c|c|c|c|c|c|}
\hline \multirow{2}{*}{ S.No. } & \multirow{2}{*}{ Business School } & \multicolumn{4}{|c|}{ Research Index $(\alpha)$} \\
\cline { 3 - 6 } & & 2012 & 2013 & 2014 & 2015 \\
\hline 1 & Wharton Business School & 3.22 & 2.977 & 2.891 & 2.22 \\
\hline 2 & Harvard Business School & 3.66 & 3.52 & 3.54 & 2.86 \\
\hline 3 & IIM, Ahmedabad, India & 2.71 & 2.34 & 2.77 & 1.60 \\
\hline 4 & ISB, Hyderabad, India & 2.533 & 3.87 & 3.022 & 2.16 \\
\hline
\end{tabular}

Table 4. The Weighted Research Index of Four Top Business Schools

\begin{tabular}{|c|c|c|c|c|c|}
\hline \multirow{2}{*}{ S.No. } & \multirow{2}{*}{ Business School } & \multicolumn{4}{|c|}{ Weighted Research Index $(\beta)$} \\
\cline { 3 - 6 } & & 2012 & 2013 & 2014 & 2015 \\
\hline 1 & Wharton Business School & 0.402 & 0.3722 & 0.3614 & 0.2773 \\
\hline 2 & Harvard Business School & 0.457 & 0.440 & 0.4434 & 0.357 \\
\hline 3 & IIM, Ahmedabad, India & 0.338 & 0.292 & 0.346 & 0.200 \\
\hline 4 & ISB, Hyderabad, India & 0.317 & 0.483 & 0.378 & 0.270 \\
\hline
\end{tabular}

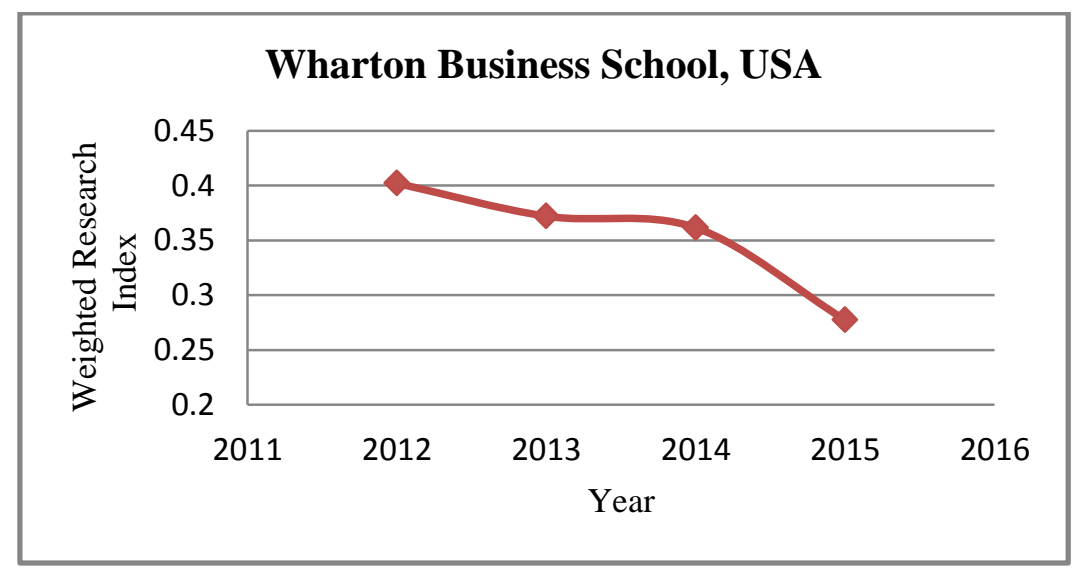

Fig.2. Variation of Weighted Research index with Year in Case of Wharton B. School 


\section{Extension of ABC Model for Universities}

Universities are different from Business schools, consisting of several departments in various faculties like Basic Sciences, Engineering \& Technology, Arts \& Humanities, Applied Sciences, Health Sciences etc. In all these faculties of the Universities, the departmental effectiveness can be measured using ABC model of determining Research productivity. The departmental research index and the weighted research index should determine the departmental competency in a given subject. In the case of University departments, acronym A stands for the number of articles published in refereed journals, B stands for the number of books published, and $\mathrm{C}$ stands for the number of book chapters written in an edited book. ABC method of measuring research productivity can also be applied for individual faculty members to determine their competency in the subject and the promotion for faculty members should not be based on their number of years experience, instead, it should be based on their annual research productivity averaged for the given duration of monitoring.

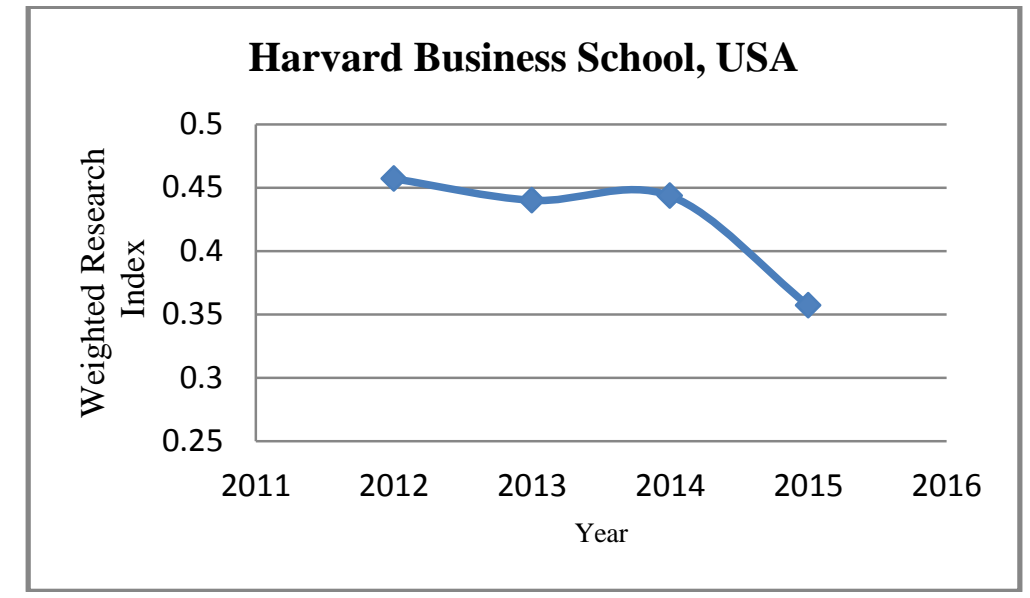

Fig.3. Variation of Weighted Research index with Year in Case of Harvard B. School

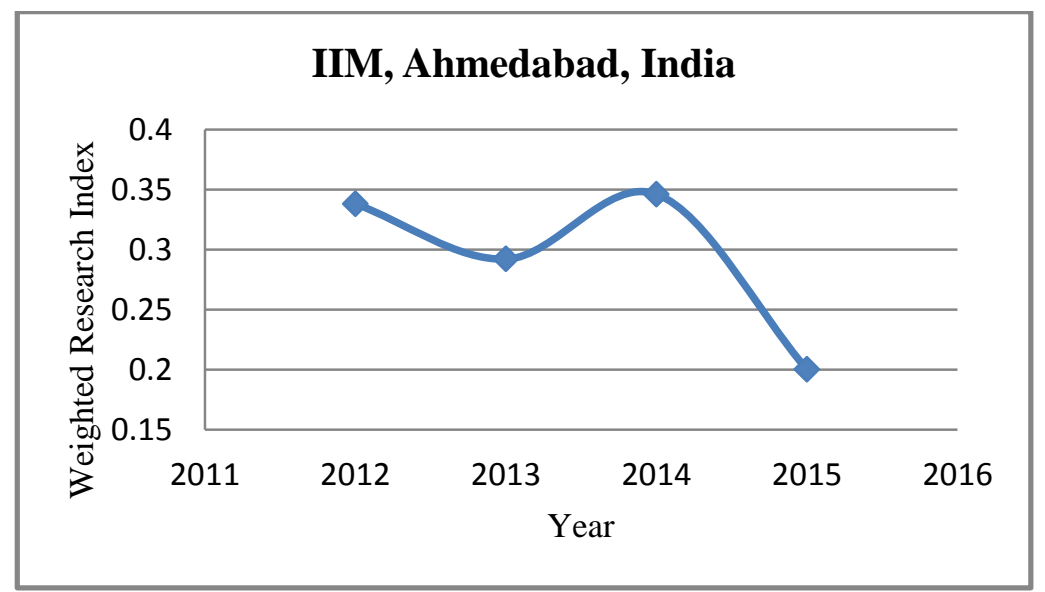

Fig.4. Variation of Weighted Research index with the Year in the Case of IIM, Ahmedabad. 


\section{Conclusion}

We have developed a new and simple model named $A B C$ model to determine the institutional research productivity based on higher educational institutions research productivity. The institutional effectiveness and competency can be scientifically measured only based on its new knowledge creation ability and the ability of its students and faculty members through research output. Higher Educational Institutional Ranking can be calculated using our ABC model. This model of ranking institutions is the only suitable, appropriate, and scientific way of allocating institutional rankings. All other criteria of institutional rankings which involve immeasurable parameters will find no way and hence any kind of lobbying/corruption in institutional ranking by various agencies can be eliminated. By making suitable modification, this $\mathrm{ABC}$ model of measuring institutional research productivity can be used to calculate faculty research performance and rank faculty members in any higher education institutions.

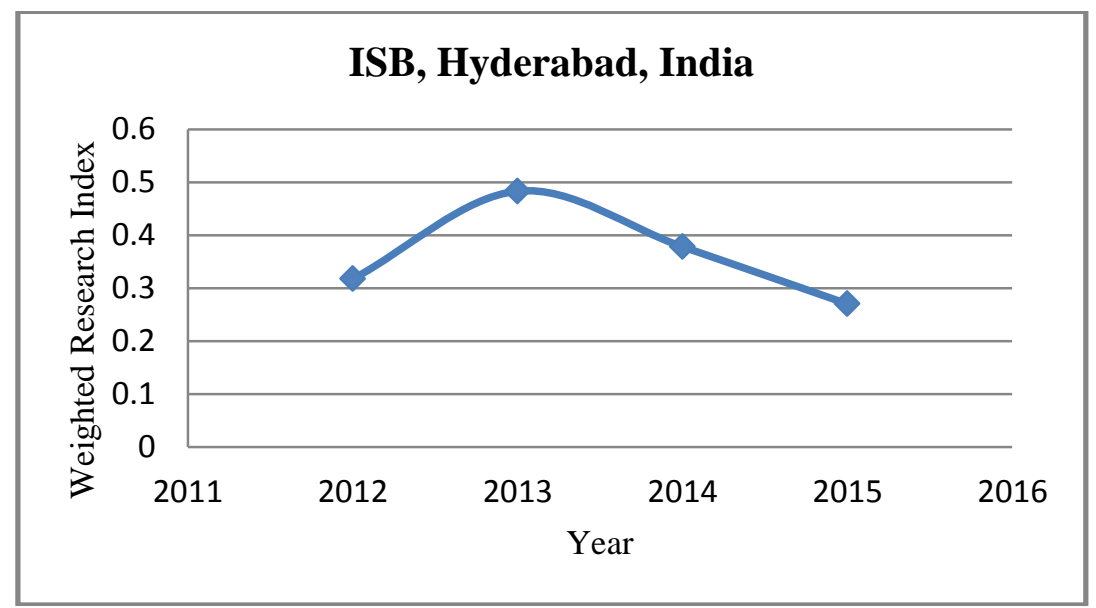

Fig.5. Variation of Weighted Research index with Last Four Year in Case of ISB, Hyderabad

\section{References}

[1] Datar, S. M., Garvin, D. A., \& Cullen, P. G. Rethinking the MBA: Business education at a crossroads. Journal of Management Development, 2011; 30(5):.451-462.

[2] Gioia, D. A., \& Corley, K. G. Being good versus looking good: Business school rankings and the Circean transformation from substance to the image. Academy of Management Learning \& Education, 2002; 1(1): 107-120.

[3] Baden-Fuller, C., Ravazzolo, F., \& Schweizer, T. Making and measuring reputations: the research ranking of European business schools. Long Range Planning, 2000; 33(5):621-650.

[4] Ray, S. C., \& Jeon, Y., Reputation and efficiency: A non-parametric assessment of America's top-rated MBA programs. European Journal of Operational Research, 2008; 189(1): 245-268.

[5] Clarke, M., The impact of higher education rankings on student access, choice, and opportunity. Higher Education in Europe, 2007; 32(1): 59-70.

[6] Linton, J. D., Perspective: Ranking business schools on the management of technology. Journal of Product Innovation Management, 2004; 21(6): 416-430.

[7] George Bickerstaffe, Bill Ridgers, Ranking of business schools, Journal of Management Development, 2007; 26 (1): $61-66$.

[8] http://bschools.businesstoday.in/ referred on 31/01/2016.

[9] https://www.nirfindia.org/\# 
[10] http://www.hbs.edu/faculty/Pages/default.aspx referred on 31/01/2016.

[11] https://www.wharton.upenn.edu/faculty-and-research/ referred on 31/01/2016.

[12] http://www.iimahd.ernet.in/faculty-and-research.html referred on 31/01/2016.

[13] http://www.isb.edu/faculty-research referred on 31/01/2016.

\section{Authors' Profiles}

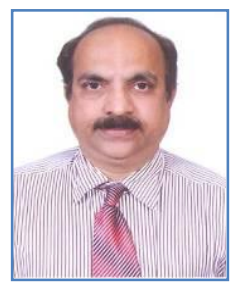

Prof. Dr. P. S. Aithal is belonging to Udupi, India, born on 04/04/1966. He has M.Sc. in Physics from Mangalore University, India, M.Sc. in E-Business from Manipal University, India, M.Tech. in Information Technology from Karnataka University, India, Ph.D. in Physics from Mangalore University, India, and Ph.D. in Management from Manipal University, India. His major fields of study are the characterization of nonlinear optical materials, optical solutions, e-commerce and mobile business. He has two years postdoctoral research experience at Physical Research Laboratory, Ahmedabad, India and one-year postdoctoral research experience at CREOL, University of Central Florida, USA, in the field of Characterization of nonlinear optical materials. He has about 22 years teaching experience both at UG and PG level in Electronics, Computer Science and Business management. Currently, he is working as PRINCIPAL at Srinivas Institute of Management Studies, Mangalore, India. He has published more than 100 research papers in peer-reviewed journals and two textbooks on physics and Electronics for Engineering students. He has the research interest in Nonlinear optical absorption, Optical Phase Conjugation, Photorefractive materials, ebusiness, m-business, ideal business, and nanotechnology business Opportunities. Dr. Aithal is the member of World Productivity Council, U.K., the member of Strategic Management Forum, India, the member of Photonics Society of India, CUSAT, Cochin, senior member of IEDRC.org, Singapore.

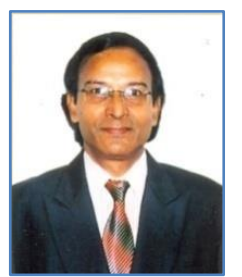

Prof. Dr. Suresh Kumar is belonging to Cochin, Kerala, India, born on 01/06/1955. He has MSW degree in Personel Management \& Industrial Relations from Kerala University, India, M.Phil. degree and Ph.D. degrees from Jawaharlal Nehru University, New Delhi, India. His major fields of study are Quality in higher education, Research productivity and innovations etc. He worked for 11 years in International Development Projects such as Indo-Dutch Rural Water Supply Project, Indo-German Fisheries Development Project, Indo- Japanese Hills Area Development Project, World Bank supported Water Supply Project etc. He has twelve years of teaching experience and served as faculty in Ethiopian Civil Service College (Addis Ababa). Presently he is working as Course Coordinator of MSW programme at Srinivas Institute of Management Studies, Mangalore. He is Life Member of International Union of Health Promotion and Education, based in Paris.

How to cite this paper: P. Sreeramana Aithal, Suresh Kumar P. M.,"ABC Model of Research Productivity and Higher Educational Institutional Ranking", International Journal of Education and Management Engineering(IJEME), Vol.6, No.6, pp.74-84, 2016.DOI: 10.5815/ijeme.2016.06.08 